\title{
Effects of management intensity and season on arboreal ant diversity and abundance in coffee agroecosystems
}

\author{
STACY M. PHILPOTT ${ }^{1,3, *}$, IVETTE PERFECTO ${ }^{2}$ and \\ JOHN VANDERMEER ${ }^{1,2}$ \\ ${ }^{1}$ Department of Ecology and Evolutionary Biology, University of Michigan, 830 North University, \\ Ann Arbor, MI 48109; ${ }^{2}$ School of Natural Resources and the Environment, University of Michigan, \\ 430 East University, Ann Arbor, MI 48109; ${ }^{3}$ Current Address: Smithsonian Migratory Bird Center, \\ National Zoological Park, 3001 Connecticut Ave. NW, Washington, DC 20008; *Author for corre- \\ spondence (e-mail: philpotts@si.edu; phone: +1-202-673-0128,fax: +1-202-633-4206)
}

Received 13 January 2004; accepted in revised form 20 September 2004

Key words: Agricultural intensification, Arboreal ants, Biodiversity, Chiapas, Coffee agroecosystem, Mexico

Abstract. Agricultural intensification decreases arthropod predator diversity, abundance and population stability, and may affect interactions between top predators and their arthropod prey ultimately affecting ecosystem services. Coffee management intensification (reduction or removal of shade trees) reduces diversity of arthropod predators (ground-foraging ants). Because ants provide ecosystem services by controlling pests, influences of intensification on arboreal, coffee-foraging ant diversity and abundance are important. We here address how coffee intensification affects: (1) coffee-foraging ant diversity and abundance and (2) seasonal fluctuations in ant abundance. In each of four coffee sites of varying management intensity in Chiapas, Mexico, we sampled vegetation and using two methods, sampled ant diversity and abundance over two years. Sites significantly differed in vegetation and management intensity. Coffee-foraging ant diversity generally decreased with increasing management intensity (16-26\% fewer species observed in the most intensivelymanaged site). Ant abundance was higher in the wet season. Management intensity, however, did not influence ant abundance or seasonal fluctuations in abundance. Our results highlight the importance of diverse agricultural systems in maintaining arthropod predator diversity, and point to one model system in which we may effectively test how diversity per se affects ecosystem services.

\section{Introduction}

Conservation biologists strive to understand how habitat disturbance affects biodiversity in natural ecosystems (Didham et al. 1998; Kalif et al. 2001; Ricketts 2001; Tscharntke et al. 2002; Watt et al. 2002), agricultural habitats (Roth et al. 1994; Estrada and Coates-Estrada 2002; Ricketts et al. 2001; Siebert 2002), or across intensification gradients of agroecosystems (Perfecto et al. 1996; Greenberg et al. 1997; Kremen et al. 2002; Klein et al. 2002a). Yet, many examine how habitat modifications affect species richness or abundance without distinguishing between agricultural types (Aberg et al. 1995; Tilman 1999, but see Glor et al. 2001; Vandermeer and Carvajal 2001; Perfecto and Vandermeer 2002) or lack quantification of vegetation variables 
necessary to distinguish habitats (Ricketts et al. 2001; Rojas et al. 2001). Agriculture covers $>75 \%$ of the earth's arable land (Young 1999) and biodiversity found therein provides ecosystem services (Balvanera et al. 2001; Klein et al. 2003).Thus quantifying effects of intensification and comparing conservation value of agricultural habitats is crucial to conservation.

Coffee (Coffea arabica) agroecosystems are highlighted for their conservation potential, but coffee management intensification eliminates biodiversity and may restrict ecosystem services. Coffee was traditionally grown under a diverse, dense shade canopy, but recent intensification includes reducing shade tree density and diversity and agrochemical use (Moguel and Toledo 1999; Mas and Dietsch 2003). With coffee intensification, diversity of predators such as ants decreases (Nestel and Dickschen 1990; Perfecto and Snelling 1995; Perfecto et al. 1996; Perfecto et al. 1997; Perfecto and Vandermeer 2002; Armbrecht and Perfecto 2003) yet no studies focus on arboreal (specifically coffeeforaging) ants (see Perfecto et al. 1996). Ants provide ecosystem services by preying on pests in agroecosystems including coffee (Way and Khoo 1992; Velez et al. 2000; Vandermeer et al. 2002) and ecosystem services may diminish as diversity is lost (Balvanera et al. 2001; Klein et al. 2003). Thus understanding losses of coffee-foraging ant diversity are particularly important.

Agroecosystem management and seasonality may also influence ant abundance. Theoretically, in vegetationally-diverse systems, predator populations are larger and more stable than in monocultures due to stable prey populations and other resources (Root 1973; Andow 1991). Empirical evidence shows some predators are more abundant in diverse (less intense) agricultural systems (Basedow 1991; Knops et al. 1999; Girma et al. 2000; Klein et al. 2002b) but management differences do not always affect ant abundance (Perfecto and Sediles 1992). Furthermore, some tropical insect populations are influenced by seasonal changes in temperature and rainfall (Tauber et al. 1998; Guedes et al. 2000) and ants are generally more abundant in the wet season (Alonso 1998; Kaspari and Weiser 2000). Thus although ant abundance may vary with management system and seasonality, abundance may fluctuate less in diverse systems.

In this study, we assess changes in diversity and abundance of coffee-foraging ants under the influences of coffee management intensification and seasonal changes investigating if: (1) Diversity of coffee-foraging ants declines with increasing management intensification; (2) Abundance of coffee-foraging ants increases with increasing management intensification; and (3) Abundance of coffee-foraging ants increases in the wet season and seasonal fluctuations in abundance are less under high-shade management.

\section{Methods}

Site description and experimental design

We set up sampling plots in four sites within three farms in the Soconusco region of SW Chiapas, Mexico: (1) Belen Rustic (TP; $15^{\circ} 15^{\prime} \mathrm{N}, 92^{\circ} 22^{\prime} \mathrm{W}$ ); (2) 
Belen Production (CPB; $\left.15^{\circ} 15^{\prime} \mathrm{N}, 92^{\circ} 23^{\prime} \mathrm{W}\right)$; (3) Irlanda (CPI; $15^{\circ} 11^{\prime} \mathrm{N}$, $92^{\circ} 20^{\prime} \mathrm{W}$ ); and (4) Hamburgo (SM; $15^{\circ} 10^{\prime} \mathrm{N}, 92^{\circ} 19^{\prime} \mathrm{W}$ ). All farms are between $950-1150 \mathrm{~m}$ elevation and receive ca. $4500 \mathrm{~mm}$ of rain per year. The sites represent a gradient of intensification based on density, diversity, and height of shade trees, and percent shade cover (Mas and Dietsch 2003; Perfecto et al. 2003). According to Moguel and Toledo's (1999) classification scheme, TP is a 'traditional polyculture', CPI and CPB are 'commercial polycultures', and SM is roughly a 'shaded monoculture'.

We sampled ants following an experimental design set up to study bird influences on coffee arthropod communities (I. Perfecto, unpublished data), thus ant sampling took place inside and outside of large bird exclosures. We set up 32 total exclosures (10 each in CPI and SM, 6 each in TP and CPB) with monofilament nylon netting $(35 \times 35 \mathrm{~mm}$ mesh) suspended from shade trees and covering roughly $10 \times 8 \mathrm{~m}$. Inside each exclosure we marked ten coffee plants for sampling and outside $(<10 \mathrm{~m}$ from exclosures) we marked ten control plants. Coffee plants in TP were larger, and nets were of set size, thus numbers of exclosure and control plants varied from seven to ten. On each sampling date we sampled a total of 200 plants each in CPI and SM, 120 in CPB, and 96 in TP. We maintained exclosures from Nov. 2000-Dec. 2002.

\section{Ant sampling and diversity analysis}

We used two methods to sample ants: vacuum samples and tuna baits. Using vacuum samples, we sampled all marked plants four times in the dry (Nov. 2000, Feb. 2001, Nov. 2001, and Nov. 2002) and three times in the wet season (May 2001, Aug. 2001, and May 2002). On several days from 7:00-9:00 AM, for each marked coffee plant, we sampled two previously unused branches ( $>6$ leaves) with a $10 \mathrm{~cm}$ diameter reversed leaf-blower (D-vac) (WeedEater ${ }^{\circledR}$ Company, 1 Poulan Drive, Nashville, AR, 71852). Arthropods were vacuumed into mesh bags, placed in plastic bags and killed with ethyl acetate. We stored samples from sets of control or exclosure plants together and later identified ants. We standardized ant abundance as number of individuals per $\mathrm{g}$ of foliage sampled. We measured length and width of all vacuumed leaves and converted leaf area to a biomass estimate using an empirically generated equation (Biomass $(\mathrm{g})=$ Leaf area $(0.025)-0.08)$.

On marked plants, we baited for ants three times in the dry (Dec. 2000, Jan. 2002, and Dec. 2002) and twice in the wet season (May 01 and May 02) (Table 1). From 7:30-10:30 AM, we placed tuna baits $(\sim 5 \mathrm{~g}) 1 \mathrm{~m}$ above ground, collected, and identified all ants found after 30-45 min. In preliminary richness analyses the ant fauna in TP was further from reaching asymptotes than other sites so we sampled 200 extra plants under similar shade conditions in TP in Dec. 2002. We stored ants separately for each plant, but to compare with D-vac samples, we grouped sets of control and exclosure plants. In months where we used both methods, D-vac samples were collected first. We 
Table 1. Vegetation characteristics sampled and totaled into a management index (MI) in four coffee sites (Belen Rustic (TP), Irlanda (CPI), Belen Production (CPB), and Hamburgo (SM)).

\begin{tabular}{lccccccc}
\hline Site & $\begin{array}{c}\text { \# tree } \\
\text { species }\end{array}$ & $\begin{array}{c}\text { \% cover } \\
\text { (Nov. 00) }\end{array}$ & $\begin{array}{c}\text { \% cover } \\
\text { (Jan. 03) }\end{array}$ & $\begin{array}{c}\% \text { two } \\
\text { species cover }\end{array}$ & $\begin{array}{c}\% \text { three } \\
\text { species cover }\end{array}$ & $\begin{array}{c}\text { Management } \\
\text { Index }\end{array}$ & N \\
\hline TP & 14.0 (a) $71.7 \pm 3.6$ (a) $75.3 \pm 2.8$ (a) & $10.3 \pm 1.6$ (a) $1.6 \pm 1.1$ & $2.19 \pm 0.19$ (a) & 6 \\
CPI & 7.3 (b) $65.0 \pm 3.6$ (a) $66.4 \pm 4.1$ (a, b) $10.6 \pm 2.4$ (a) $0.2 \pm 0.2$ & $2.88 \pm 0.14$ (b) & 10 \\
CPB & 6.5 (b) $42.3 \pm 3.7$ (b) $59.0 \pm 3.5$ (b) & $0.7 \pm 0.4$ (b) 0 & $3.60 \pm 0.089$ (c c $\left.^{a}\right)$ & 6 \\
SM & 3.0 (c) $30.4 \pm 2.1$ (b) $35.6 \pm 3.2$ (c) & $1.0 \pm 0.4$ (b) 0 & $4.07 \pm 0.06$ (d) & 10 \\
$p$ & $* * *$ & $* * *$ & $* * *$ & $* *$ & NS & $* *$ & \\
\hline
\end{tabular}

${ }^{* *} p<0.01,{ }^{* * *} p<0.001,{ }^{a} \mathrm{CPB}-\mathrm{SM}, p=0.067$

Numbers show means (tree species richness, percent cover, proportion of shade points with two or three species' cover, and MI values) \pm standard error for $35 \times 35 \mathrm{~m}$ area (50 points) surrounding each of 32 bird exclosures. A higher MI shows more intensive coffee management. Letters show significant differences between sites based on Tukey's post-hoc tests.

recorded ant activity per bait for each species separately using an index where $0=$ no ants, $1=1$ to 2 ants, $2=3-10$ ants, $3 \geq 10$ ants, and summed across species for total activity per plant. Mean activity was calculated as average total activity per plant for a set of control or exclosure plants.

We analyzed species richness data using EstimateS (Colwell and Coddington 1994; http://www/viceroy/eeb/uconn/.edu/estimates) for tuna and D-vac samples and for both data sets combined. We used sets of exclosure or control plants as samples for between site comparisons. Because sample sizes differed between sites we compared richness between sites with rarefaction (Gotelli and Colwell 2001). We used Coleman estimates, virtually indistinguishable from rarefaction (Colwell and Coddington 1994). To approximate total richness per site we used richness estimators (Chao2, Incidence-Based Coverage Estimator [ICE], and Michaelis-Menten Means [MMMeans]) that estimate total richness per site based on observed species richness plus the number of uniques (species found in only one sample) rather than singletons (species represented by only one individual) (Longino et al. 2002). EstimateS also calculated diversity indices (Fisher's alpha, 2) Shannon's index, and 3) Simpson's index (inverse of program results reported here). For all calculations we used presence/ absence data not abundance because ants are social insects (Longino et al. 2002). With simple linear regression we examined relationships between a Management Index (MI) (see below), diversity indices, and species richness.

\section{Vegetation sampling}

We sampled shade tree diversity, percent shade cover, and structural diversity and summarized vegetation data using a management index (MI). In Nov. 2000 , we counted the number of tree species in a $35 \times 35 \mathrm{~m}$ area around each 
exclosure. In the same area, at fifty points ( $>5 \mathrm{~m}$ apart) we recorded: (1) foliage presence using a vertical tube densiometer and (2) tree species (one or more) directly above each point and calculated percent cover (\% points with foliage) and structural diversity (proportion of points covered by two or three species). In Jan. 2003, we re-measured percent cover to account for changes in management during the time exclosures were maintained. We summarized vegetation variables per exclosure using the MI (Mas and Dietsch 2003) whereby raw data are converted to a scale from 0 to 1 and then summed. We divided values for each variable (\% cover in Nov. 2000 and Jan. 2003, \# shade tree species, and proportion of points with two or three species) by the highest overall value, and then subtracted this from 1 . All values were summed for a total possible of 5 , where 5 is most- and 0 is least-intensively managed.

\section{Statistical analyses}

To differentiate between percent cover, structural diversity, tree richness, and MI we used ANOVA with site as a main factor. To assess differences in ant activity with sampling date and with season we used ANOVA. To determine seasonal fluctuations in ant abundance under differing management intensities, we calculated the coefficient of variation (CV) (the ratio of standard deviation in abundance for each date to mean abundance) for each site. For ant abundance, we used untransformed data for tuna baits and square-root transformed data for D-vac data to meet assumptions of normality. We used Tukey's posthoc tests to make pair-wise comparisons where site differences were detected.

\section{Results}

Vegetation and management system

Sites significantly differed for each vegetation variable and MI where TP was generally the most shaded, CPI and CPB were intermediate, and SM was least shady (Table 1). Tree richness differed with site $\left(F_{3,28}=63, p<0.001\right)$ and TP had more than double the number of tree species of CPI, CPB or SM $(p<0.001)$, and CPI and CPB had twice as many species as SM $(p<0.001)$. Tree richness in CPI and CPB did not differ $(p=0.752)$. In both Nov. 2000 $\left(F_{3,28}=36.34, p<0.001\right)$ and Jan. $2003\left(F_{3,28}=22.98, p<0.001\right)$ percent canopy cover differed between sites. In Nov. 2000, cover was higher in TP and CPI than in CPB and SM $(p<0.001)$, CPB tended to have higher cover than SM $(p=0.080)$, but cover in TP and CPI did not differ $(p=0.507)$. In Jan. 2003, percent canopy cover was higher in TP, CPI and CPB than in SM $(p<0.001)$, but CPI did not differ from TP $(p=0.364)$ or CPB $(p=0.526)$. Structural diversity differed between sites as well (two-species cover, $F_{3,28}=11.33, p<0.001$; three-species cover, $\left.F_{3,28}=2.333, p=0.096\right)$. TP 
and CPI had ten times more points covered with two species than CPB and SM $(p<0.007)$, and TP and CPI were the only sites with points covered by three species. MI values also differed with site $\left(F_{3,28}=42.23, p<0.001\right)$. All sites significantly differed from one another $(p<0.004)$, and in order from highest to lowest shade were TP, CPI, CPB, and SM, but differences between TP and SM were only marginally significant $(p=0.067)$.

\section{Ant diversity and management system}

We collected a total of 81 ant species (67 with D-vac sampling and 57 with tuna baits) (Appendix 1). For both sampling methods the majority of ant species (D-vac, 61.2\%; baits, 50\%) were collected from fewer than ten samples. The most commonly encountered ants found in D-vac samples were Brachymyrmex sp. 1 (29.2\% of samples), Brachymyrmex heeri (24.6\%), Nesomyrmex echinatinodis $(23.8 \%)$, and Pseudomyrmex simplex (23.6\%). The most commonly encountered ants at tuna baits were Brachymyrmex heeri (29.3\%), Azteca instabilis $(28.7 \%)$, P. simplex (26.3\%), and $N$. echinatinodis $(23.9 \%)$.

Species richness differed with site and sampling method (Figure 1). In general, more species were captured with the D-vac (Figure 1), but rarefaction curves were closer to reaching asymptotes for baiting. For baits, ant richness was highest in TP, slightly lower in CPB, even lower in CPI, and lowest in SM (Figure 1a). For D-vac samples, CPB was substantially richer than other sites. TP had the second highest richness followed by CPI and SM, which had the lowest number of species (Figure 1b). For methods combined, CPB had slightly higher richness than TP (one species more) but both sites were much richer than CPI followed by SM (Figure 1c).

Estimates of total richness per site varied with sampling method and estimator but overall richness patterns were similar to observed results (Figure 2, Table 2). For tuna baiting, TP estimates were higher ( $8-39 \%$ more species) and SM estimates were lower (20-26\% fewer species) than CPI and CPB, but estimates for CPI and CPB were within three species of one another (Table 2). Estimated richness was similar to observed richness (within 12 species) for all sites. For D-vac samples, however, richness estimates far exceeded observed numbers (up to 20 species more) - especially for TP where estimated richness was up to $61 \%$ higher than observed richness (Table 2), reflecting that we sampled less of the total community using this method. In general, however, estimated richness for TP, CPB, and CPI was higher than SM (11-45\% more species). For samples combined, estimated richness for TP and CPB was similar (within 4 species). Estimated richness in TP and CPB was higher than for CPI (with 6 to 15 more species). SM was the least rich site with up to 10 fewer estimated species than CPI (Table 2).

Generally, diversity indices declined with increasing management, but results varied with the way the ant community was sampled (Table 2). For tuna bait data TP was more diverse than CPI and CPB which were more diverse than 

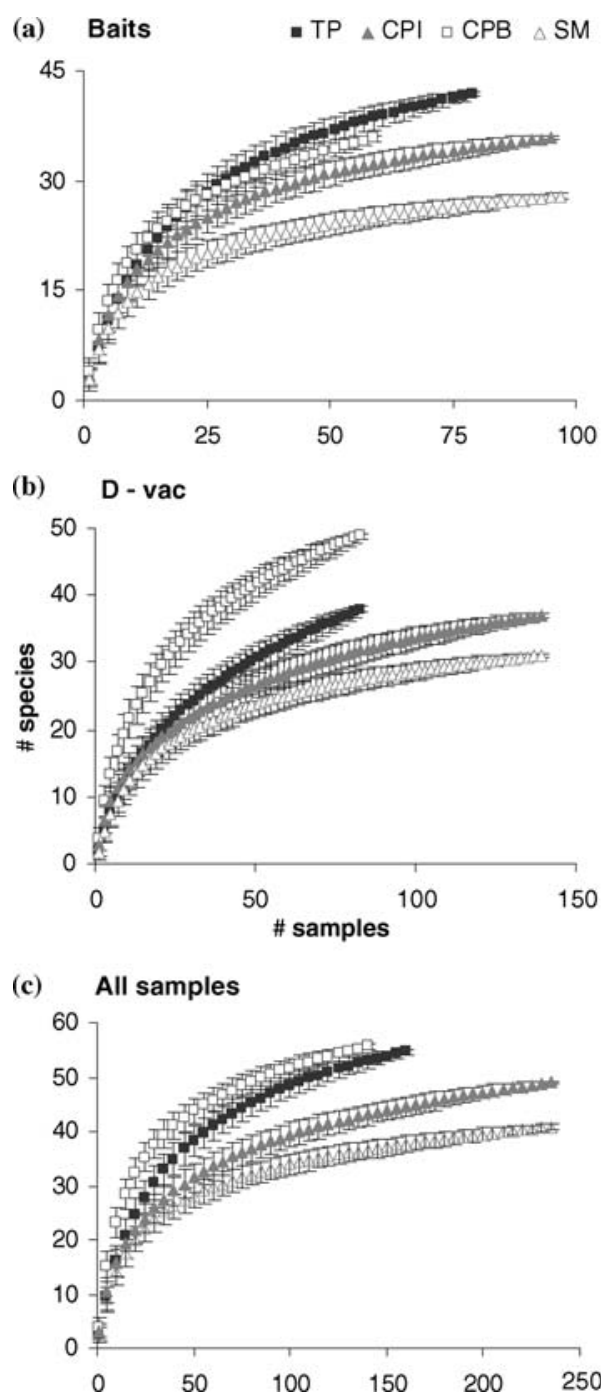

Figure 1. Arboreal ant species rarefaction curves in four coffee sites organized from most shady to least shady: Belen Rustic (TP), Irlanda (CPI), Belen Production (CPB), and Hamburgo (SM) in Chiapas, Mexico. Letters show rarefaction (Coleman) curves for (a) tuna baits, (b) D-vac samples, and (c) for all samples combined generated with EstimateS. Closed symbols show more shady sites, and open symbols show less shady sites.

SM. D-vac results were not as clear, but showed a general trend towards lower diversity in SM. For Fisher's alpha, TP was more diverse than all other sites, and SM was least diverse. Shannon Index values were higher in CPB than in TP and lowest in CPI. Simpson's values were the same for TP, CPB, and SM and lower in CPI. For all samples combined, general patterns showed TP and 

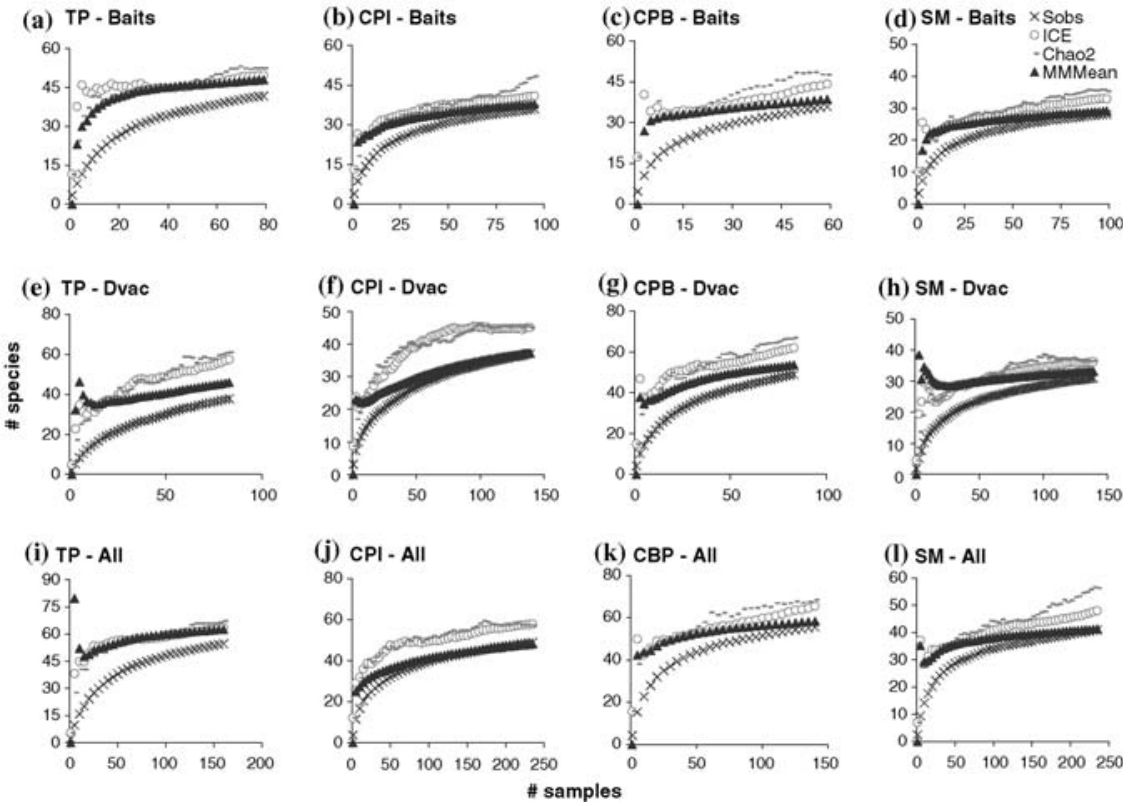

Figure 2. Ant species accumulation curves in four coffee sites of increasing management intensity (Belen Rustic (TP), Irlanda (CPI), Belen Production (CPB) and Hamburgo (SM)) for observed richness (SOBS), and for species richness estimators (ICE - Incidence-based Coverage Estimator; Chao2; MMMeans - Michaelis-Menten Means) created with EstimateS. Richness was assessed with tuna baits $(\mathrm{a}-\mathrm{d}), \mathrm{D}$-vac samples $(\mathrm{e}-\mathrm{h})$, and for both sampling methods combined (i-1).

CPB to be more diverse than CPI and SM (Table 2). Fisher's alpha was highest for TP and lowest for SM. Shannon and Simpson's values were highest for CPB and lowest for CPI.

Overall, increasing management intensity (i.e. higher MI) correlated with decreasing observed and estimated ant species richness $\left(R^{2}=0.1389\right.$, $\left.y=-5.7718 \mathrm{x}+65.893, F_{1,46}=7.477, p=0.009\right)$, but did not correlate to changes in diversity index values $\left(R^{2}=0.0146, y=-0.8751 x+8.183\right.$, $\left.F_{1,34}=0.507, p=0.481\right)$.

Ant abundance and activity by season, management system

Ant abundance was somewhat higher in the wet season, but management intensity did not affect either ant abundance or seasonal fluctuations in abundance. Ant abundance at tuna baits was $21 \%$ higher $\left(F_{1,126}=16.26\right.$, $p<0.001$ ) and with D-vac samples 19\% (not significantly) higher in the wet season $\left(F_{1,126}=0.144, p=0.705\right)$ (Figure 3$)$. In three of five tuna sampling dates, and for all D-vac sampling dates, ant abundance differed with site (Figure 3, Table 3). To assess if site differences reflected changes in manage- 
Table 2. Ant species richness (observed and estimated) and diversity indices for two sampling methods for four coffee sites (Belen Rustic (TP), Irlanda (CPI), (Belen Production (CPB), and Hamburgo (SM)).

\begin{tabular}{lcccclll}
\hline Site & SOBs & ICE & Chao2 & MM-Mean & Fisher's & Shannon & Simpson \\
\hline \multicolumn{2}{l}{ Tuna baiting } \\
TP & 42.00 & 50.23 & 53.00 & 48.01 & 14.83 & 3.25 & 0.95 \\
CPI & 36.00 & 40.97 & 48.80 & 37.77 & 9.78 & 2.96 & 0.93 \\
CPB & 36.00 & 44.26 & 47.11 & 38.57 & 11.21 & 3.08 & 0.94 \\
SM & 28.00 & 32.91 & 35.20 & 29.07 & 7.34 & 2.79 & 0.92 \\
D-vac Sampling & & & & & & \\
TP & 38.00 & 57.69 & 61.27 & 46.02 & 15.05 & 3.07 & 0.94 \\
CPI & 37.00 & 44.92 & 44.69 & 37.42 & 9.69 & 2.80 & 0.91 \\
CPB & 49.00 & 62.00 & 66.31 & 53.77 & 15.43 & 3.24 & 0.94 \\
SM & 31.00 & 36.33 & 36.44 & 33.18 & 8.99 & 2.94 & 0.94 \\
All samples combined & & & & & & \\
TP & 55.00 & 63.83 & 68.00 & 62.75 & 17.09 & 3.40 & 0.95 \\
CPI & 49.00 & 57.89 & 57.07 & 48.14 & 11.48 & 3.00 & 0.93 \\
CPB & 56.00 & 65.70 & 67.08 & 58.58 & 14.98 & 3.49 & 0.96 \\
SM & 41.00 & 48.22 & 57.20 & 41.43 & 9.97 & 3.07 & 0.94 \\
\hline
\end{tabular}

Numbers show observed richness (SOBs), estimated richness (Incidence-based Coverage Estimator (ICE), Chao2, and Michaelis-Menten Means (MM-Mean), and diversity indices (Fisher's, Shannon, and Simpson, all calculated with EstimateS.

ment intensity, we summed all Tukey's tests where 1) abundance was significantly lower in sites with lower MI, 2) abundance was significantly higher in sites with lower MI, and 3) where abundance did not differ. In 8 of 72 possible pair-wise comparisons, ant abundance was greater in the more intensively managed site, and in 10 of 72 comparisons abundance was greater in less intensively managed site. In most comparisons (54 of 72, $75 \%$ ); however, ant abundance did not differ with differences in management intensity.

Ant abundance did not fluctuate less with season under less intense management. For tuna baiting, the CV of abundance was higher in SM (0.289) than in CPI (0.194) or CPB (0.174), but was highest for TP $(0.353)$, the site with the lowest MI. For D-vac samples, the CV was higher in CPB (0.688) than in CPI $(0.525)$ or TP $(0.439)$, but was lowest in SM (0.298), the site with the highest MI.

\section{Discussion}

The four coffee sites selected differed for most vegetation variables and for the MI where TP was least intensively managed, CPI and CPB were intermediate, 

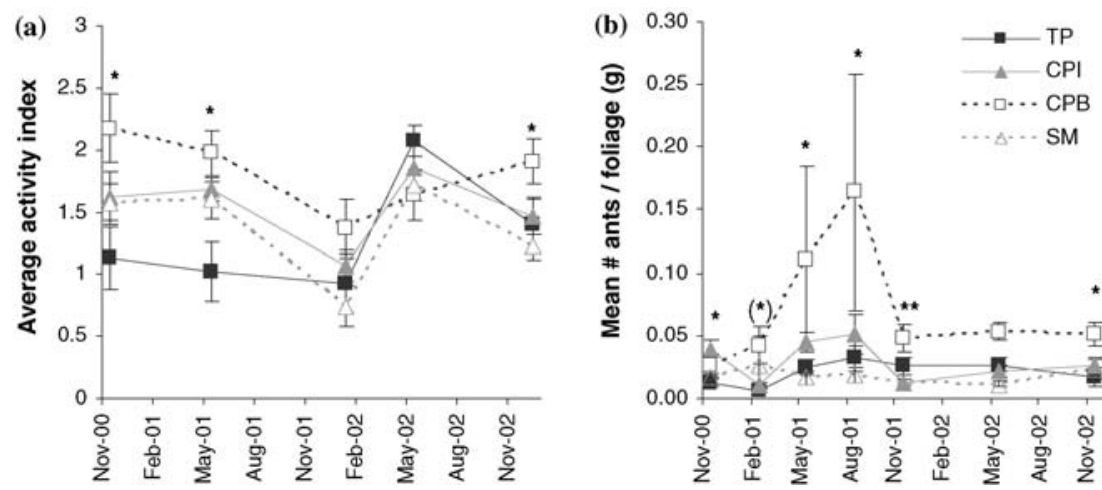

Figure 3. Effect of coffee management system and season on ant activity (a, tuna baits) and abundance (b, D-vac samples) in four coffee sites (Belen Rustic (TP), Irlanda (CPI), Belen Production (CPB) and Hamburgo (SM)) over a two year period. The dry season dates fall between November-April and wet season dates fall between May-October. Bars show standard error. Significant differences shown with asterisks are explained in the text and Table 3.

and SM was most intensively managed. Overall, increasing MI correlated with decreasing coffee-foraging ant richness. For tuna samples, higher management intensity reflected increased ant diversity. For D-vac sampling, ant diversity was still lowest under the highest management intensity, but differences between intermediate and high-shade sites were less clear, and diversity tended to be higher in CPB, a more intensely-managed site by some measures. Thus patterns of diversity loss depended somewhat on sampling method. Ant abundance was higher in the wet season, but abundance did not differ with management intensity, nor did abundance fluctuate less in less intensively managed sites.

Species richness estimators varied greatly in number of species estimated for a sampling method and site. In general, MMMeans and ICE were closest to reaching asymptotes and seemed to be the most reliable. MMMeans returned estimates closest to observed richness and was closest to reaching asymptotes, perhaps showing a minimum number of species per site/method. ICE returned higher estimates, but was also close to reaching asymptotes. These two estimators have shown high performance previously for tropical ants in Costa Rica (Longino et al. 2002) and for tropical trees (Chazdon et al. 1998). In contrast, Chao2 behavior was more erratic and sometimes not close to reaching asymptotes, even for where observed species accumulation curves were leveling off (Figure 2). For example, accumulation curves for SM for all methods combined was close to an asymptote, yet Chao2 estimates were sharply raising.

Overall, we found more ant species in D-vac samples than with tuna baits, likely due to differences in the ant communities sampled or due to interspecific competition. Tuna baits tend to attract generalist ants, perhaps from a larger foraging range including the ground and canopy, yet baits do not attract all 
Table 3. ANOVA results comparing ant activity (tuna baiting) and abundance (\# ants/foliage (g), D-vac sampling) between four coffee sites under differing management intensity.

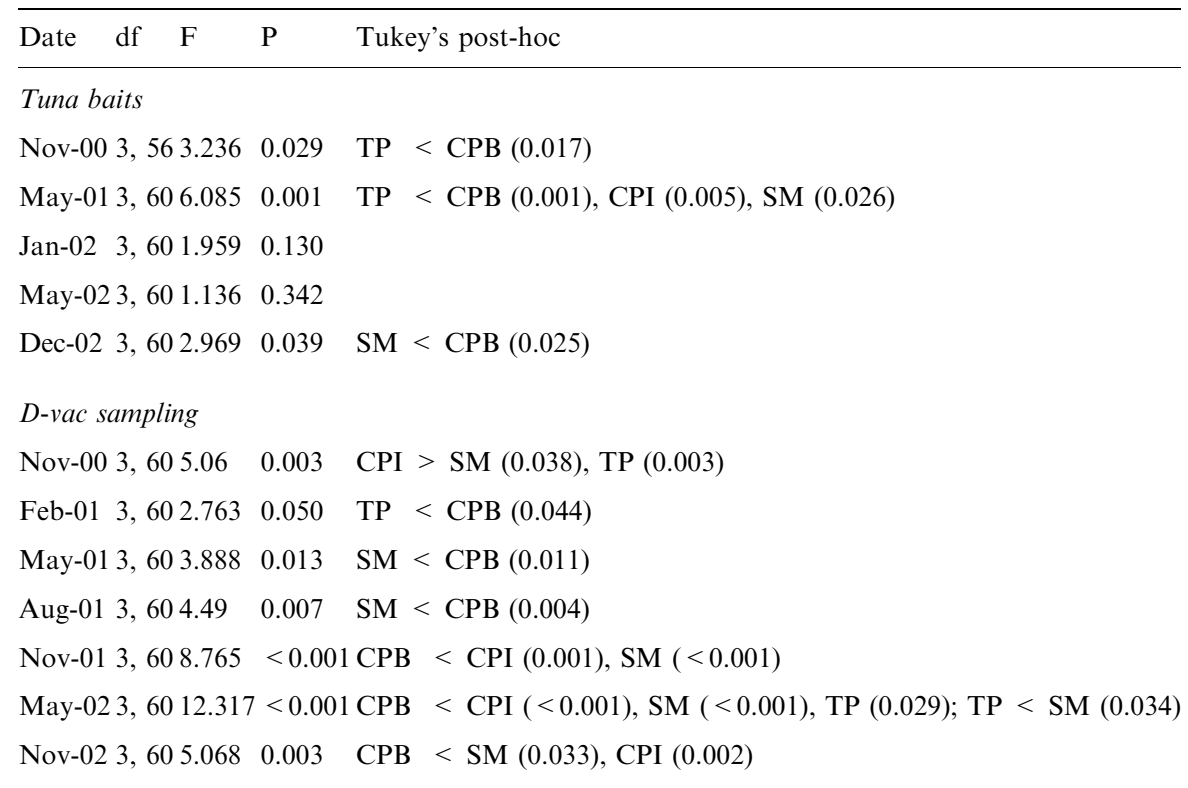

Results were calculated using untransformed data for tuna baiting and square-root transformed data for D-vac sampling. Tukey's post-hoc results ( $p$-value in parenthesis) show significant site differences where sites in order from least to most intensively managed are: TP - Belen Rustic, CPI - Irlanda, CPB - Belen Production and SM - Hamburgo.

ants in the community. D-vac samples, on the other hand, will catch most ants foraging on coffee plants regardless of their diet preferences. Thus, the ant community sampled by tuna baits may be in part a subset of ants captured in D-vac samples, but may also include some ants more generally restricted to shade trees or the ground. Additionally, tuna baits attract some competitively dominant ants (such as Solenopsis geminata) that may have eliminated other ant species from baits before they were checked (Perfecto 1994).

Although ant diversity generally declined with increasing MI, this was not always the case, perhaps because habitat management is not the only factor controlling diversity. Ant richness in D-vac samples was exceptionally high in $\mathrm{CPB}$, a more intensively managed site. Competitive interactions between ants may also strongly impact diversity within areas. For example, presence of Solenopsis geminata may restrict ant richness by excluding other ant species (Perfecto 1994). Surprisingly, CPB, the site with the highest overall richness, did not have any samples with Solenopsis geminata. It may be possible that absence of this ant in CPB allows other ants to exist there, thereby increasing richness. Additionally, although habitat characteristics may strongly affect species diversity (Collinge et al. 2003), regional factors such as distance from forest, (Ricketts et al. 2001; Perfecto and Vandermeer 2002) or landscape 
patterns such as extent of high-quality habitat and habitat arrangement may also be important (Vandermeer and Carvajal 2001; Steffan-Dewenter 2002; Weibull et al. 2003). Land-use history may also influence patterns of biodiversity loss such that species loss lags behind habitat destruction (Tilman et al. 1994). The landscape surrounding CPB includes fewer intensively managed coffee farms and more forest fragments than do CPI and SM (Pers. obsv.). CPB was recently converted to more intense management $(<5$ years ago) and thus may be still undergoing species loss whereas CPI and SM have been under similar management for $>20$ years (G. Ibarra-Nuñez, Pers. comm.). These three factors may explain why diversity in $\mathrm{CPB}$ was relatively high compared with CPI, a similarly managed farm. Richness and diversity in CPB was even slightly higher than in the least intensively managed site (TP). Although in this study we focus on coffee-foraging ants, all sites and in particular TP, may include arboreal ants more restricted to the shade tree layer that nonetheless may sometimes forage in the coffee plants. Given that accumulation curves were furthest from reaching asymptotes for TP, the true richness of arboreal ants foraging in the coffee layer may be much higher than our samples indicate. Furthermore, we did not sample nocturnally foraging ants that may account for a large part of the ant community. The inclusion of these ants may significantly alter the results found here.

In conclusion, coffee-foraging ant diversity, but not ant abundance, tended to decrease with increasing coffee management intensification. Many debate the relative importance of diversity and abundance in determining the function of biodiversity or ecosystem services (Balvanera et al. 2001; Kremen et al. 2002; Klein et al. 2003). Here, ant abundance was not changed, yet ant diversity (including both ground- and coffee-foraging ants) is affected by management intensity. Coffee may thus serve as a model system for investigating the interplay between diversity, abundance, and ecosystem services.

\section{Acknowledgements}

We thank J.A. Garcia-Ballinas, P. Bichier, G. Lopez, J. Maldonado, B.E. Chilel, R. Velasquez, J.C. Mendez Lopez, A. Mendez Mendizabal, A. Hammond, F.B. Camposeco Silvestre, J.L. Cabrera Santos, L.H.L. Ramirez, A. Gonzalez, G. Dominguez, and S. Uno for field help. I. Armbrecht, J. Longino, B. McKay, R. Snelling, and P. Ward assisted in ant identification. I. Armbrecht and R. Burnham commented on the manuscript. The Peters and Edelman families and the ISMAM Cooperative allowed us to work on their farms. G. Ibarra-Núñez from El Colegio de la Frontera Sur in Tapachula provided logistical support. This research was supported by NSF Grant \#DEB-9981526 to I. Perfecto, R. Greenberg, and G. Ibarra-Núñez, the Helen Olsen Brower Fellowship in Environmental Science of the University of Michigan, and an NSF Graduate Research Fellowship to S. Philpott. 
Appendix 1. Ant species (organized by subfamilies) found in four coffee farms using tuna baits and D-vac sampling or for both methods combined over a 2-year sampling period.

\begin{tabular}{|c|c|c|c|c|c|c|c|c|c|c|c|c|}
\hline \multirow[b]{2}{*}{ Species } & \multicolumn{4}{|c|}{ All methods } & \multicolumn{4}{|c|}{ Baits } & \multicolumn{4}{|c|}{ D-vac } \\
\hline & $\mathrm{TP}$ & CPI & $\mathrm{CPB}$ & SM & $\mathrm{TP}$ & CPI & $\mathrm{CPB}$ & SM & $\mathrm{TP}$ & CPI & $\mathrm{CPB}$ & SM \\
\hline \multicolumn{13}{|l|}{ Dolichoderinae } \\
\hline Azteca instabilis & $\mathrm{x}$ & $\mathrm{x}$ & $\mathrm{x}$ & $\mathrm{x}$ & $\mathrm{x}$ & $\mathrm{x}$ & $\mathrm{x}$ & $\mathrm{x}$ & $\mathrm{x}$ & $\mathrm{x}$ & $\mathrm{x}$ & $\mathrm{x}$ \\
\hline Azteca sp. 1 & & & $\mathrm{x}$ & & & & & & & & $\mathrm{x}$ & \\
\hline Azteca sp. 2 & $\mathrm{x}$ & $\mathrm{x}$ & $\mathrm{x}$ & $\mathrm{x}$ & $\mathrm{x}$ & $\mathrm{x}$ & $\mathrm{x}$ & $\mathrm{x}$ & $\mathrm{x}$ & & $\mathrm{x}$ & \\
\hline Azteca sp. 3 & & & $\mathrm{x}$ & $\mathrm{x}$ & & & & & & & $\mathrm{x}$ & $\mathrm{x}$ \\
\hline Dolichoderus debilis & & $\mathrm{x}$ & & & & $\mathrm{x}$ & & & & & & \\
\hline Dolichoderus lutosus & & & $\mathrm{x}$ & & & & $\mathrm{x}$ & & & & $\mathrm{x}$ & \\
\hline Dorymyrmex sp. 1 & & & & $\mathrm{x}$ & & & & $\mathrm{x}$ & & & & \\
\hline Linepithema sp. 1 & $\mathrm{x}$ & & & & $\mathrm{x}$ & & & & & & & \\
\hline Tapinoma sp. 1 & & & $\mathrm{x}$ & & & & $\mathrm{x}$ & & & & & \\
\hline Tapinoma sp. 2 & $\mathrm{x}$ & & $\mathrm{x}$ & & & & & & $\mathrm{x}$ & & $\mathrm{x}$ & \\
\hline Tapinoma sp. 3 & $\mathrm{x}$ & & $\mathrm{x}$ & & & & & & $\mathrm{x}$ & & $\mathrm{x}$ & \\
\hline Technomyrmex sp. 1 & $\mathrm{x}$ & & $\mathrm{x}$ & & $\mathrm{x}$ & & $\mathrm{x}$ & & & & & \\
\hline Technomyrmex sp. 2 & $\mathrm{x}$ & $\mathrm{x}$ & $\mathrm{x}$ & $\mathrm{x}$ & & & $\mathrm{x}$ & $\mathrm{x}$ & $\mathrm{x}$ & $\mathrm{x}$ & $\mathrm{x}$ & $\mathrm{x}$ \\
\hline \multicolumn{13}{|l|}{ Ecitoninae } \\
\hline Labidus coecus & & $\mathrm{x}$ & $\mathrm{x}$ & & & $\mathrm{x}$ & & & & & $\mathrm{x}$ & \\
\hline \multicolumn{13}{|l|}{ Formicinae } \\
\hline Brachymyrmex heeri & $\mathrm{x}$ & $\mathrm{x}$ & $\mathrm{x}$ & $\mathrm{x}$ & $\mathrm{x}$ & $\mathrm{x}$ & $\mathrm{x}$ & $\mathrm{x}$ & $\mathrm{x}$ & $\mathrm{x}$ & $\mathrm{x}$ & $\mathrm{x}$ \\
\hline Brachymyrmex sp. 1 & $\mathrm{x}$ & $\mathrm{x}$ & $\mathrm{x}$ & $\mathrm{x}$ & $\mathrm{x}$ & $\mathrm{x}$ & $\mathrm{x}$ & $\mathrm{x}$ & $\mathrm{x}$ & $\mathrm{x}$ & $\mathrm{x}$ & $\mathrm{x}$ \\
\hline Brachymyrmex sp. 2 & $\mathrm{x}$ & $\mathrm{x}$ & $\mathrm{x}$ & $\mathrm{x}$ & & & & & $\mathrm{x}$ & $\mathrm{x}$ & $\mathrm{x}$ & $\mathrm{x}$ \\
\hline Brachymyrmex sp. 3 & & $\mathrm{x}$ & $\mathrm{x}$ & & & & $\mathrm{x}$ & & & $\mathrm{x}$ & $\mathrm{x}$ & \\
\hline Camponotus abscisus & & & & $\mathrm{x}$ & & & & & & & & \\
\hline Camponotus canescens & $\mathrm{x}$ & $\mathrm{x}$ & $\mathrm{x}$ & & $\mathrm{x}$ & $\mathrm{x}$ & & & $\mathrm{x}$ & & $\mathrm{x}$ & \\
\hline Camponotus novogranadensis & $\mathrm{x}$ & $\mathrm{x}$ & $\mathrm{x}$ & & $\mathrm{x}$ & $\mathrm{x}$ & $\mathrm{x}$ & & & & $\mathrm{x}$ & \\
\hline Camponotus senex & $\mathrm{x}$ & & & & $\mathrm{x}$ & & & & $\mathrm{x}$ & & & \\
\hline Camponotus senex textor & $\mathrm{x}$ & $\mathrm{x}$ & $\mathrm{x}$ & $\mathrm{x}$ & $\mathrm{x}$ & $\mathrm{x}$ & $\mathrm{x}$ & $\mathrm{x}$ & & $\mathrm{x}$ & $\mathrm{x}$ & $\mathrm{x}$ \\
\hline Camponotus sericeiventris & $\mathrm{x}$ & & $\mathrm{x}$ & & $\mathrm{x}$ & & $\mathrm{x}$ & & & & & \\
\hline Camponotus striatus & $\mathrm{x}$ & & $\mathrm{x}$ & & $\mathrm{x}$ & & $\mathrm{x}$ & & & & $\mathrm{x}$ & \\
\hline Camponotus sp. 1 & $\mathrm{x}$ & $\mathrm{x}$ & $\mathrm{x}$ & & $\mathrm{x}$ & & $\mathrm{x}$ & & $\mathrm{x}$ & $\mathrm{x}$ & & \\
\hline Myrmelachista sp. 1 & $\mathrm{x}$ & $\mathrm{x}$ & & & & & & & $\mathrm{x}$ & $\mathrm{x}$ & & \\
\hline Myrmelachista sp. 2 & & $\mathrm{x}$ & & & & $\mathrm{x}$ & & & & $\mathrm{x}$ & & \\
\hline Myrmelachista sp. 3 & $\mathrm{x}$ & $\mathrm{x}$ & $\mathrm{x}$ & $\mathrm{x}$ & $\mathrm{x}$ & $\mathrm{x}$ & & & $\mathrm{x}$ & $\mathrm{x}$ & $\mathrm{x}$ & $\mathrm{x}$ \\
\hline Myrmelachista sp. 4 & $\mathrm{x}$ & & $\mathrm{x}$ & & & & & & $\mathrm{x}$ & & $\mathrm{x}$ & \\
\hline
\end{tabular}


Appendix 1. Continued.

\begin{tabular}{|c|c|c|c|c|c|c|c|c|c|c|c|c|}
\hline \multirow[b]{2}{*}{ Species } & \multicolumn{4}{|c|}{ All methods } & \multicolumn{4}{|c|}{ Baits } & \multicolumn{4}{|c|}{ D-vac } \\
\hline & $\mathrm{TP}$ & CPI & $\mathrm{CPB}$ & $\mathrm{SM}$ & $\mathrm{TP}$ & CPI & $\mathrm{CPB}$ & $\mathrm{SM}$ & $\mathrm{TP}$ & CPI & $\mathrm{CPB}$ & SN \\
\hline Paratrechina sp. 1 & & & $\mathrm{x}$ & & & & & & & & $\mathrm{x}$ & \\
\hline Paratrechina sp. 2 & & & $\mathrm{x}$ & & & & & & & & $\mathrm{x}$ & \\
\hline \multicolumn{13}{|l|}{ Myrmicincae } \\
\hline Cephalotes sp. 1 & $\mathrm{x}$ & $\mathrm{x}$ & & & $\mathrm{x}$ & $\mathrm{x}$ & & $\mathrm{x}$ & $\mathrm{x}$ & & & \\
\hline Crematogaster spp. & $\mathrm{x}$ & $\mathrm{x}$ & $\mathrm{x}$ & $\mathrm{x}$ & $\mathrm{x}$ & $\mathrm{x}$ & $\mathrm{x}$ & $\mathrm{x}$ & & & & \\
\hline Crematogaster carinata & $\mathrm{x}$ & $\mathrm{x}$ & $\mathrm{x}$ & $\mathrm{x}$ & & & $\mathrm{x}$ & & $\mathrm{x}$ & $\mathrm{x}$ & $\mathrm{x}$ & $\mathrm{x}$ \\
\hline Crematogaster crinosa & $\mathrm{x}$ & $\mathrm{x}$ & $\mathrm{x}$ & $\mathrm{x}$ & $\mathrm{x}$ & $\mathrm{x}$ & $\mathrm{x}$ & $\mathrm{x}$ & $\mathrm{x}$ & $\mathrm{x}$ & $\mathrm{x}$ & $\mathrm{x}$ \\
\hline Crematogaster formosa & $\mathrm{x}$ & & & & $\mathrm{x}$ & & & & $\mathrm{x}$ & & & \\
\hline Crematogaster hirsuta & & & & $\mathrm{x}$ & & & & & & & & $\mathrm{x}$ \\
\hline Crematogaster negrapilosa & $\mathrm{x}$ & $\mathrm{x}$ & $\mathrm{x}$ & $\mathrm{x}$ & $\mathrm{x}$ & $\mathrm{x}$ & $\mathrm{x}$ & $\mathrm{x}$ & & & $\mathrm{x}$ & \\
\hline Crematogaster sumichrasti & $\mathrm{x}$ & & $\mathrm{x}$ & $\mathrm{x}$ & $\mathrm{x}$ & & $\mathrm{x}$ & $\mathrm{x}$ & $\mathrm{x}$ & & $\mathrm{x}$ & $\mathrm{x}$ \\
\hline Crematogaster sp. 1 & $\mathrm{x}$ & & $\mathrm{x}$ & & $\mathrm{x}$ & & $\mathrm{x}$ & & & & & \\
\hline Crematogaster sp. 2 & $\mathrm{x}$ & & & & $\mathrm{x}$ & & & & $\mathrm{x}$ & & & \\
\hline Monomorium floricola & $\mathrm{x}$ & $\mathrm{x}$ & $\mathrm{x}$ & $\mathrm{x}$ & & & & & $\mathrm{x}$ & $\mathrm{x}$ & $\mathrm{x}$ & $\mathrm{x}$ \\
\hline Monomorium pharoanis & $\mathrm{x}$ & & $\mathrm{x}$ & & $\mathrm{x}$ & & & & & & $\mathrm{x}$ & \\
\hline Monomorium sp. 1 & & & & $\mathrm{x}$ & & & & & & & & $\mathrm{x}$ \\
\hline Nesomyrmex echanatinodis & $\mathrm{x}$ & $\mathrm{x}$ & $\mathrm{x}$ & $\mathrm{x}$ & $\mathrm{x}$ & $\mathrm{x}$ & $\mathrm{x}$ & $\mathrm{x}$ & $\mathrm{x}$ & $\mathrm{x}$ & $\mathrm{x}$ & $\mathrm{x}$ \\
\hline Nesomyrmex pittieri & $\mathrm{x}$ & $\mathrm{x}$ & $\mathrm{x}$ & & $\mathrm{x}$ & $\mathrm{x}$ & $\mathrm{x}$ & & $\mathrm{x}$ & $\mathrm{x}$ & $\mathrm{x}$ & \\
\hline Pheidole indestincta & $\mathrm{x}$ & $\mathrm{x}$ & $\mathrm{x}$ & $\mathrm{x}$ & $\mathrm{x}$ & $\mathrm{x}$ & $\mathrm{x}$ & $\mathrm{x}$ & $\mathrm{x}$ & $\mathrm{x}$ & $\mathrm{x}$ & $\mathrm{x}$ \\
\hline Pheidole punctatissima & $\mathrm{x}$ & $\mathrm{x}$ & $\mathrm{x}$ & $\mathrm{x}$ & $\mathrm{x}$ & $\mathrm{x}$ & $\mathrm{x}$ & $\mathrm{x}$ & & $\mathrm{x}$ & $\mathrm{x}$ & \\
\hline Pheidole susannae & & & $\mathrm{x}$ & & & & & & & & $\mathrm{x}$ & \\
\hline
\end{tabular}

Pheidole sp. 1 $\mathrm{x}$

Pheidole sp. 2

Pheidole sp. 3

Pheidole sp. 4

Pheidole sp. 5

Pheidole sp. 6

Pheidole sp. 7

Pheidole sp. 8

$\begin{array}{llllllllllll}\mathrm{X} & \mathrm{X} & \mathrm{X} & \mathrm{X} & \mathrm{X} & \mathrm{X} & \mathrm{X} & \mathrm{X} & \mathrm{X} & \mathrm{X} & \mathrm{X} & \mathrm{X}\end{array}$

$\begin{array}{lllll}\mathrm{X} & \mathrm{X} & \mathrm{X} & \mathrm{X} & \mathrm{X}\end{array}$

$\begin{array}{lllll}\mathrm{X} & \mathrm{X} & \mathrm{X} & \mathrm{X} & \mathrm{X}\end{array}$

Pheidole sp. 9

Pheidole sp. 10

Procryptocerus scabriusculus $\quad \mathrm{x} \quad \mathrm{x} \quad \mathrm{x}$

Pyramica sp. 1

$\mathrm{x}$

Solenopsis geminata 
Appendix 1. Continued.

\begin{tabular}{|c|c|c|c|c|c|c|c|c|c|c|c|c|}
\hline \multirow[b]{2}{*}{ Species } & \multicolumn{4}{|c|}{ All methods } & \multicolumn{4}{|c|}{ Baits } & \multicolumn{4}{|c|}{ D-vac } \\
\hline & $\mathrm{TP}$ & CPI & $\mathrm{CPB}$ & SM & $\mathrm{TP}$ & CPI & $\mathrm{CPB}$ & $\mathrm{SM}$ & TP & CPI & $\mathrm{CPB}$ & SM \\
\hline Solenopsis sp. 1 & $\mathrm{x}$ & $\mathrm{x}$ & $\mathrm{x}$ & $\mathrm{x}$ & $\mathrm{x}$ & $\mathrm{x}$ & $\mathrm{x}$ & $\mathrm{x}$ & & $\mathrm{x}$ & $\mathrm{x}$ & $\mathrm{x}$ \\
\hline Solenopsis sp. 2 & $\mathrm{x}$ & $\mathrm{x}$ & & $\mathrm{x}$ & $\mathrm{x}$ & $\mathrm{x}$ & & & $\mathrm{x}$ & $\mathrm{x}$ & & $\mathrm{x}$ \\
\hline Solenopsis sp. 3 & $\mathrm{x}$ & $\mathrm{x}$ & $\mathrm{x}$ & & & & & & $\mathrm{x}$ & $\mathrm{x}$ & $\mathrm{x}$ & \\
\hline Wasmannia auropunctata & $\mathrm{x}$ & $\mathrm{x}$ & $\mathrm{x}$ & $\mathrm{x}$ & $\mathrm{x}$ & $\mathrm{x}$ & $\mathrm{x}$ & $\mathrm{x}$ & $\mathrm{x}$ & & $\mathrm{x}$ & \\
\hline \multicolumn{13}{|l|}{ Poneromorph } \\
\hline Gnamptogenys striatula & & $\mathrm{x}$ & $\mathrm{x}$ & & & $\mathrm{x}$ & $\mathrm{x}$ & & & $\mathrm{x}$ & $\mathrm{x}$ & \\
\hline Hyperponera sp. 1 & $\mathrm{x}$ & & & & $\mathrm{x}$ & & & & & & & \\
\hline Pachycondyla apicales & $\mathrm{x}$ & $\mathrm{x}$ & $\mathrm{x}$ & $\mathrm{x}$ & & & & & $\mathrm{x}$ & $\mathrm{x}$ & $\mathrm{x}$ & $\mathrm{x}$ \\
\hline \multicolumn{13}{|l|}{ Pseudomyrmecinae } \\
\hline Pseudomyrmex ejectus & $\mathrm{x}$ & $\mathrm{x}$ & $\mathrm{x}$ & $\mathrm{x}$ & $\mathrm{x}$ & $\mathrm{x}$ & $\mathrm{x}$ & $\mathrm{x}$ & $\mathrm{x}$ & $\mathrm{x}$ & $\mathrm{x}$ & $\mathrm{x}$ \\
\hline Pseudomyrmex elongatus & $\mathrm{x}$ & $\mathrm{x}$ & $\mathrm{x}$ & $\mathrm{x}$ & $\mathrm{x}$ & $\mathrm{x}$ & $\mathrm{x}$ & $\mathrm{x}$ & & $\mathrm{x}$ & $\mathrm{x}$ & $\mathrm{x}$ \\
\hline Pseudomyrmex gracilis & $\mathrm{x}$ & $\mathrm{x}$ & $\mathrm{x}$ & $\mathrm{x}$ & $\mathrm{x}$ & $\mathrm{x}$ & $\mathrm{x}$ & $\mathrm{x}$ & $\mathrm{x}$ & & $\mathrm{x}$ & \\
\hline Pseudomyrmex occulatus & & & & $\mathrm{x}$ & & & & $\mathrm{x}$ & & & & \\
\hline Pseudomyrmex PSW-06 & $\mathrm{x}$ & $\mathrm{x}$ & & & & & & & $\mathrm{x}$ & $\mathrm{x}$ & & \\
\hline Pseudomyrmex PSW-53 & $\mathrm{x}$ & $\mathrm{x}$ & & $\mathrm{x}$ & $\mathrm{x}$ & $\mathrm{x}$ & & $\mathrm{x}$ & $\mathrm{x}$ & $\mathrm{x}$ & & $\mathrm{x}$ \\
\hline Pseudomyrmex simplex & $\mathrm{x}$ & $\mathrm{x}$ & $\mathrm{x}$ & $\mathrm{x}$ & $\mathrm{x}$ & $\mathrm{x}$ & $\mathrm{x}$ & $\mathrm{x}$ & $\mathrm{x}$ & $\mathrm{x}$ & $\mathrm{x}$ & $\mathrm{x}$ \\
\hline Pseudomyrmex sp. 1 & & $\mathrm{x}$ & & & & & & & & $\mathrm{x}$ & & \\
\hline Pseudomyrmex sp. 2 & & $\mathrm{x}$ & & & & $\mathrm{x}$ & & & & & & \\
\hline Pseudomyrmex sp. 3 & & & $\mathrm{x}$ & & & & & & & & $\mathrm{x}$ & \\
\hline Pseudomyrmex sp. 4 & & $\mathrm{x}$ & & $\mathrm{x}$ & & & & & & $\mathrm{x}$ & & $\mathrm{x}$ \\
\hline Total species observed & 55 & 49 & 56 & 41 & 42 & 36 & 36 & 28 & 38 & 37 & 49 & 31 \\
\hline
\end{tabular}

\section{References}

Aberg J., Jansson G., Swenson J.E. and Angelstam P. 1995. The effect of matrix on the occurrence of Hazel Grouse (Bonasa bonasia) in isolated habitat fragments. Oecologia 103: 265-269.

Alonso L.E. 1998. Spatial and temporal variation in the ant occupants of a facultative ant-plant. Biotropica 30: 201-213.

Andow D.A. 1991. Vegetational diversity and arthropod population response. Ann. Rev. Entomol. 36: $561-586$.

Armbrecht I. and Perfecto I. 2003. Litter-twig dwelling ant species richness and predation potential within a forest fragment and neighboring coffee plantations of contrasting habitat quality in Mexico. Agric. Ecosyst. Environ. 97: 107-115.

Balvanera P., Daily G.C., Ehrlich P.R., Ricketts T.H., Bailey S.A., Kark S., Kremen C. and Pereira H. 2001. Conserving biodiversity and ecosystem services. Science 291: 2047. 
Basedow T. 1991. Population-density and biomass of epigeal predatory arthropods, natural enemies of insect pests, in winter-wheat fields of areas with extremely different intensity of agricultural production. J. Plant Dis. Prot. 98: 371-377.

Chazdon R.L., Colwell R.K., Denslow J.S. and Guariguata M.R. 1998. Statistical methods for estimating species richness of woody regeneration in primary and secondary rain forests of northeastern Costa Rica. In: Dallmeier F. and Comiskey J.A. (eds), Forest Biodiversity Research, Monitoring and Modeling: Conceptual Background and Old World Case Studies. Parthenon Publishing, Paris, France, pp. 285-309.

Collinge S.K., Prudic K.L. and Oliver J.C. 2003. Effects of local habitat characteristics and landscape context on grassland butterfly diversity. Conserv. Biol. 17: 178-187.

Colwell R.K. and Coddington J.A. 1994. Estimating terrestrial biodiversity through extrapolation. Philos. Trans. R. Soc. London Ser. B 345: 101-118.

Didham R.K., Hammond P.M., Lawton J.H., Eggleton P. and Stork N.E. 1998. Beetle species responses to tropical forest fragmentation. Ecol. Monogr. 68: 295-323.

Estrada A. and Coates-Estrada R. 2002. Dung beetles in continuous forest, forest fragments and in an agricultural mosaic habitat island at Los Tuxtlas, Mexico. Biodiv. Conserv. 11: 19031918.

Girma H., Rao M.R. and Sithanantham S. 2000. Insect pests and beneficial arthropods population under different hedgerow intercropping systems in semiarid Kenya. Agroforest. Syst. 50: 279-292.

Glor R.E., Flecker A.S., Benard M.F. and Power A.G. 2001. Lizard diversity and agricultural disturbance in a Caribbean forest landscape. Biodiv. Conserv. 10: 711-723.

Gotelli N.J. and Colwell R.K. 2001. Quantifying biodiversity: procedures and pitfalls in the measurement and comparison of species richness. Ecol. Lett. 4: 379-391.

Greenberg R., Bichier P. and Sterling J. 1997. Bird populations in rustic and planted shade coffee plantations of Eastern Chiapas, Mexico. Biotropica 29: 501-514.

Guedes R.N.C., Zanuncio T.V., Zanuncio J.C. and Medeiros A.G.B. 2000. Species richness and fluctuation of defoliator Lepidoptera populations in Brazilian plantations of Eucalyptus grandis as affected by plant age and weather factors. Forest Ecol. Manag. 137: 179-184.

Kalif K.A.B., Azevedo-Ramos C., Moutinho P. and Malcher S.A.O. 2001. The effect of logging on the ground-foraging ant community in Eastern Amazonia. Stud. Neotropical Fauna Environ. 36: 215-219.

Kaspari M. and Weiser M.D. 2000. Ant activity along moisture gradients in a neotropical forest. Biotropica 32: 703-711.

Klein A., Steffan-Dewenter I. and Tscharntke T. 2003. Fruit set of highland coffee increases with the diversity of pollinating bees. Proc. R. Soc. London B 270: 955-961.

Klein A.M., Steffan-Dewenter I., Buchori D. and Tscharntke T. 2002. Effects of land-use intensity in tropical agroforestry systems on coffee flower-visiting and trap-nesting bees and wasps. Conserv. Biol. 16: 1003-1014.

Klein A.M., Steffan-Dewenter I. and Tscharntke T. 2002. Predator-prey ratios on cocoa along a land-use gradient in Indonesia. Biodiv. Conserv. 11: 683-693.

Knops J.M.H., Tilman D., Haddad N.M., Naeem S., Mitchell C.E., Haarstad J., Ritchie M.E., Howe K.M., Reich P.B., Siemann E. and Groth J. 1999. Effects of plant species richness on invasion dynamics, disease outbreaks, insect abundances and diversity. Ecol. Lett. 2:286-293.

Kremen C., Williams N.M. and Thorp R.W. 2002. Crop pollination from native bees at risk from agricultural intensification. Proc. Natl. Acad. Sci. USA 99: 16812-16816.

Longino J.T., Coddington J. and Colwell R.K. 2002. The ant fauna of a tropical rain forest: Estimating species richness three different ways. Ecology 83: 689-702.

Mas A.H. and Dietsch T.V. 2003. An index of management intensity for coffee agroecosystems to evaluate butterfly species richness. Ecol. Appl. 13: 1491-1501.

Moguel P. and Toledo V.M. 1999. Biodiversity conservation in traditional coffee systems of Mexico. Conserv. Biol. 13: 11-21.

Nestel D. and Dickschen F. 1990. The foraging kinetics of ground ant communities in different Mexican coffee agroecosystems. Oecologia 84: 58-63. 
Perfecto I. 1994. Foraging behavior as a determinant of asymmetric competitive interaction between 2 ant species in a tropical agroecosystem. Oecologia 98: 184-192.

Perfecto I., Mas A., Dietsch T. and Vandermeer J. 2003. Conservation of biodiversity in coffee agroecosystems: a tri-taxa comparison in southern Mexico. Biodiv. Conserv. 12: 1239-1252.

Perfecto I., Rice R.A., Greenberg R. and VanderVoort M.E. 1996. Shade coffee: a disappearing refuge for biodiversity. Bioscience 46: 598-608.

Perfecto I. and Sediles A. 1992. Vegetational diversity, ants (Hymenoptera, Formicidae), and herbivorous pests in a neotropical agroecosystem. Environ. Entomol. 21: 61-67.

Perfecto I. and Snelling R. 1995. Biodiversity and the transformation of a tropical agroecosystem ants in coffee plantations. Ecol. Appl. 5: 1084-1097.

Perfecto I. and Vandermeer J. 2002. Quality of agroecological matrix in a tropical montane landscape: ants in coffee plantations in southern Mexico. Conserv. Biol. 16: 174-182.

Perfecto I., Vandermeer J., Hanson P. and Cartin V. 1997. Arthropod biodiversity loss and the transformation of a tropical agroecosystem. Biodiv. Conserv. 6: 935-945.

Ricketts T.H. 2001. The matrix matters: Effective isolation in fragmented landscapes. Am. Nat. 158: 87-99.

Ricketts T.H., Daily G.C., Ehrlich P.R. and Fay J.P. 2001. Countryside biogeography of moths in a fragmented landscape: Biodiversity in native and agricultural habitats. Conserv. Biol. 15: 378-388.

Rojas L., Godoy C., Hanson P., Kleinn C. and Hilje L. 2001. Hopper (Homoptera: Auchenorrhyncha) diversity in shaded coffee systems of Turrialba, Costa Rica. Agroforest. Syst. 53: 171-177.

Root R.B. 1973. Organization of a plant-arthropod association in simple and diverse habitats fauna of collards (Brassica oleracea). Ecol. Monogr. 43: 95-120.

Roth D.S., Perfecto I. and Rathcke B. 1994. The effects of management systems on groundforaging ant diversity in Costa Rica. Ecol. Appl. 4: 423-436.

Siebert S.F. 2002. From shade- to sun-grown perennial crops in Sulawesi, Indonesia: implications for biodiversity conservation and soil fertility. Biodiv. Conserv. 11: 1889-1902.

Steffan-Dewenter I. 2002. Landscape context affects trap-nesting bees, wasps, and their natural enemies. Ecol. Entomol. 27: 631-637.

Tauber M.J., Tauber C.A., Nyrop J.P. and Villani M.G. 1998. Moisture, a vital but neglected factor in the seasonal ecology of insects: Hypotheses and tests of mechanisms. Environ. Entomol. 27: $523-530$.

Tilman D. 1999. Global environmental impacts of agricultural expansion: The need for sustainable and efficient practices. Proc. Natl. Acad. Sci. USA 96: 5995-6000.

Tilman D., May R.M., Lehman C.L. and Nowak M.A. 1994. Habitat Destruction and the Extinction Debt. Nature 371: 65-66.

Tscharntke T., Steffan-Dewenter I., Kruess A. and Thies C. 2002. Characteristics of insect populations on habitat fragments: A mini review. Ecol. Res. 17: 229-239.

Vandermeer J. and Carvajal R. 2001. Metapopulation dynamics and the quality of the matrix. Am. Nat. 158: 211-220.

Vandermeer J., Perfecto I., Ibarra-Nunez G., Philpott S. and Garcia-Ballinas J.A. 2002. Ants (Azteca sp.) as potential biological control agents in organic shade coffee production in Southern Chiapas, Mexico: complication of indirect effects. Agroforest. Syst. 56: 271-276.

Velez M., Bustillo A.E. and Posada F.J. 2000. Predación sobre Hypothenemus hampei, (Ferrari) de las hormigas Solenopsis spp., Pheidole spp., y Dorymyrmex spp. durante el secado del café. In: Vélez M., Bustillo A.E. and Posada F.J. (eds), Resúmenes XXVII Congreso. Sociedad Colombiana de Entomología, Medellín, Colombia, pp. 17.

Watt A.D., Stork N.E. and Bolton B. 2002. The diversity and abundance of ants in relation to forest disturbance and plantation establishment in southern Cameroon. J. Appl. Ecol. 39: 18-30.

Way M.J. and Khoo K.C. 1992. Role of ants in pest-management. Ann. Rev. Entomol. 37: 479-503.

Weibull A.C., Ostman O. and Granqvist A. 2003. Species richness in agroecosystems: the effect of landscape, habitat and farm management. Biodiv. Conserv. 12: 1335-1355.

Young A. 1999. Is there really spare land? A critique of estimates of available cultivable land in developing countries. Environ. Dev. Sustainability 1: 3-18. 